Article

\title{
Do Profitable Banks Make a Positive Contribution to the Economy?
}

\author{
Vijay Kumar ${ }^{1, *}$ and Ron Bird ${ }^{2}$ \\ 1 New Zealand Institute for Business Research, The University of Waikato, Hamilton 3240, New Zealand \\ 2 School of Accounting, Finance and Economics, The University of Waikato, Hamilton 3240, New Zealand; \\ ron.bird@waikato.ac.nz \\ * Correspondence: vijay.kumar@waikato.ac.nz
}

Received: 30 May 2020; Accepted: 22 July 2020; Published: 24 July 2020

\begin{abstract}
A number of studies have investigated the relationship between financial sector development and economic growth; however, the impact of bank profitability on economic growth is still unclear. We investigate the link between bank profitability and economic growth in the Asia-Pacific region over the period 2004-2014. Using the system GMM estimator, our findings suggest that a profitable banking sector is a prerequisite for economic growth in the Asia-Pacific region and that the impact of bank profitability on economic growth is more prominent in small banking sectors. Perhaps surprisingly, we found that the bank size has a negative impact on GDP growth, with the influence of bank profitability on economic growth reducing as the size of the banking sector increases. Our results also show that the impact of profitability on economic growth is much larger in developed economies compared to small emerging and large emerging economies.
\end{abstract}

Keywords: economic growth; financial sector development; global financial crisis; bank profitability

\section{Introduction}

The banking sector is an important component of the financial system (Dia et al. 2020). Banks create additional wealth in the economy by attracting funds from depositors and channel these funds to investors. Dietrich and Wanzenried (2011) argued that the smooth running of a country's economic activities depends on the efficient banking system. Levine and Zervos (1998) suggested that banks foster economic growth by funding productive projects and are a prerequisite for economic growth (Levine et al. 2000). Given the importance of the banking sector in economies, it is not surprising that it has been the subject of much academic interest, or that there is still much disagreement as to the extent of the contribution that it makes. Most of the previous studies have focused on different measures of bank size in order to explain the contributions of the banking system to the economic development. Only a few studies have investigated the impacts of bank profitability on economic growth. A profitable banking sector plays an important role in overcoming the economic shocks (Athanasoglou et al. 2008). European Central Bank (2016) suggested that profitable banks are able to attract capital from investors and are also likely to generate capital through their retained earnings. Trujillo-Ponce (2013) argued that the profitability of banks is also essential for the sustainability of the banking system and that profitable banks are able to inject funds into the economy by providing loans. There is also empirical evidence suggesting that profitable banks are less likely to fail (Claeys and Schoors 2007). Hence, bank profitability is considered one of the key measures for predicting bank failures, using measures such as the Z-Score and the CAMELS rating system. A number of studies have indicated a direct link between financial stability and economic growth. Creel et al. (2015) found that financial instability resulted in negative economic growth in the EU. There are also other studies that support this notion. For example, studies by Levine (1997) and Wachtel (2001) indicated that the 
financial sector development promotes economic growth. Similarly, a number of studies have indicated that bank failures reduce economic growth (see Bernanke 1983; Calomiris and Mason 2003; Anari et al. 2005). Since existing research shows that bank profitability leads to financial stability and reduces bank failures, and there is evidence that financial stability and reduced bank failures have a positive impact on economic growth ${ }^{1}$, our study aims to investigate the dynamic relationship between profitable banks and economic growth across ten economies in the Asia-Pacific region ${ }^{2}$ over the period 2004-2014.

A number of studies have investigated determinants of the profitability of banks (Athanasoglou et al. 2008; Dietrich and Wanzenried 2011; Kumar et al. 2020); however, there is limited research on the consequences of bank profitability. The literature on the determinants of the profitability of banks suggests that bank size, credit risk management, bank liquidity, and cost management are key drivers of bank profitability. In addition, a number of studies have empirically investigated the relationship between financial sector development and economic growth. Most of these studies have used the bank size to measure financial sector development. Therefore, the impact of bank profitability on economic growth is still unclear. To our knowledge, only a few studies have explored this relationship. Using data from 133 countries, Klein and Weill (2017) suggested that profitable banks make a significant contribution to economic growth, and Cole et al. (2008) found a positive relationship between the stock returns of banks and economic growth. Our study differs from these previous investigations. Cole et al. (2008) focused on the link between bank stock returns and economic growth while we use return on bank assets (ROA) as an independent variable to investigate the impacts of bank profitability on economic growth. Klein and Weill (2017) used global data to investigate the impact of bank profitability on economic growth. Given that banks around the world operate under different policies and regulations, the findings of their study cannot be generalized to the Asia-Pacific region. We also investigate the causal relationship between bank profitability and economic growth and identify how the impact of bank profitability varies across different economies.

Our study makes significant contributions by investigating the impacts of bank profitability on economic growth and adds a new strand to the literature on the relationship between financial sector development and economic growth. This research makes three important contributions to the existing literature. First, this is the first study that investigates the impact of bank profitability on economic growth across a range of countries in the Asia-Pacific region that are at different stages of economic development but are operating within a similar regulatory setting. ${ }^{3}$ Second, this study identifies how the impact of bank profitability varies across economies in our sample: Small emerging, large emerging, and developed economies. Third, this study investigates the causal relationship between bank profitability and economic growth. One of the major objectives of policy makers is to achieve targeted economic growth. Knowledge of whether or not bank profitability promotes economic growth would help policy makers make important decisions related to the structure of the banking sector.

We found that the profitable banks are the key drivers of economic growth. Our results suggest a positive relationship between bank profitability in period $(t-1)$ and economic growth in period (t). Our findings suggest that an increase in bank profitability increases economic growth, while an increase in the banking sector size decreases economic growth, indicating that bank profitability is more important than the banking sector size in order to drive economic growth. We also found that the impact of bank profitability on economic growth reduces with the increase in banking sector size. In terms of macroeconomic variables, our findings confirm a negative relationship between inflation and economic growth, and a positive relationship between government expenditure and economic growth.

The remainder of this paper is structured in the following manner: In Section 2, we provide a brief overview of the banking sectors of the ten countries in our study. Section 3 discusses the existing

Refer to the conceptual nexus between bank profitability and economic growth in Figure A1 (Appendix A).

The countries are Australia, Bangladesh, China, Hong Kong, India, Indonesia, Japan, Malaysia, Pakistan, and Singapore.

For example, most of the central banks in these countries require banks to maintain capital adequacy ratios and a certain percentage of deposits as cash reserves. 
literature. Section 4 discusses dependent and independent variables. Section 5 highlights data sources and methods. In Section 6, we present and discuss our empirical results. Section 7 presents a summary of findings.

\section{Overview of the Banking Sectors}

This study focuses on commercial banks, which are the most important part of any financial system, being the key suppliers of credit in the economy (World Bank 2005). The exchange of domestic and international payments between different parties are done through banking channel; therefore, an efficient banking system is necessary for smooth running of economic activities.

This study focuses on ten countries in the Asia-Pacific region, which are at different stages of economic development. However, the banking regulations are similar across the countries. We classified these countries in three categories based on the state of their economy; i.e., small emerging economies, large emerging economies, and developed economies. In this section, we briefly discuss some institutional and regulatory characteristics of the banking sectors of the nations in our study.

\subsection{Small Emerging Economies}

Bangladesh, Indonesia, Malaysia, and Pakistan are small emerging economies in our study. All these countries have also Islamic banks which operate in parallel with the conventional banks.

Table 1 highlights the regulatory and institutional characteristics of the banking system in these four countries. The table shows that Malaysia has the largest banking sector in terms of total assets, while there are more banks in Indonesia compared to other countries. The table demonstrates that financial inclusion is very low in these countries, ranging from eight branches per 100,000 adults in Bangladesh to eleven branches per 100,000 adults in Malaysia. The bank assets to GDP ratio is highest $(193 \%)$ in Malaysia and lowest in Indonesia (42\%).

Table 1. Regulatory and institutional characteristics of banking systems in small emerging economies.

\begin{tabular}{|c|c|c|c|c|}
\hline Country Name & Bangladesh & Indonesia & Malaysia & Pakistan \\
\hline Total assets (USD) & 107 billion & 440 billion & 602 billion & 100 billion \\
\hline Number of conventional banks & 48 & 109 & 37 & 28 \\
\hline * Number of Islamic banks & 25 & 34 & 16 & 20 \\
\hline Minimum capital adequacy ratio requirement ${ }^{4}$ & $10 \%$ & $8 \%$ & $8 \%$ & $10 \%$ \\
\hline Cash reserve requirement & $5 \%$ & $6 \%$ & $4 \%$ & $5 \%$ \\
\hline Non-performing loan (NPL) criteria & +90 days & +365 days & +90 days & +90 days \\
\hline Financial inclusion (branches/100,000 adults) & 8 & 9.6 & 11 & 9 \\
\hline Bank assets to GDP ratio & $80 \%$ & $42 \%$ & $193 \%$ & $43 \%$ \\
\hline
\end{tabular}

* Includes full-fledged Islamic banks and Islamic windows of conventional banks. Source: Data related to total assets and number of banks, capital adequacy ratio requirement, cash reserve requirement, and non-performing loan criteria were collected from the websites of central banks. Data related to financial inclusion and bank assets to GDP ratio were collected from the World Bank database.

\subsection{Large Emerging Economies}

China and India are the large emerging economies in our sample. The banking sectors in both countries have experienced a number of reforms. The purpose of these reforms was to improve the performance of banks and to bring their operations more into line with international standards.

The regulatory and institutional characteristics of Chinese and Indian banks are reported in Table 2. The Chinese banking sector is larger than India's, with total assets of US 24.3 trillion compared to US 1.8 trillion for the Indian banking sector. Financial inclusion in both countries is low, with eight branches per 100,000 adults in China and twelve branches per 100,000 adults in India. The bank assets to GDP ratio is higher in China (292\%), compared to $95 \%$ in India.

4 Capital adequacy ratio is the amount of capital maintained by banks to cover unexpected losses (Anandarajan et al. 2007). 
Table 2. Regulatory and institutional characteristics of banking systems in large emerging economies.

\begin{tabular}{ccc}
\hline Country Name & China & India \\
\hline Total assets (USD) & 24.5 trillion & 1.8 trillion \\
Number of banks & 672 & 89 \\
Minimum capital adequacy ratio requirement & $8.50 \%$ & $9.00 \%$ \\
Cash reserve requirement & $19 \%$ & $4 \%$ \\
Non-performing loan (NPL) criteria & +90 days & +90 days \\
Financial inclusion (branches/100,000 adults) & 8 & 12 \\
Bank assets to GDP ratio & $292 \%$ & $95 \%$ \\
\hline
\end{tabular}

Source: Data related to total assets and number of banks in India were obtained from the Reserve Bank of India. Data related to total assets and number of banks in China were obtained from the annual reports of the Chinese Banking Regulation Commission. Information about capital adequacy ratio requirements and cash reserve requirements was collected from the websites of central banks of India and China. Data related to financial inclusion and bank assets to GDP ratio were collected from the World Bank database.

\subsection{Developed Economies}

The developed economies in our study include Australia, Hong Kong, Japan, and Singapore. Table 3 highlights the regulatory and institutional characteristics of the banking system in these four countries. The total assets of Japanese banking sector are US 8 trillion which makes it the largest banking sector among developed economies in the sample. Financial inclusion is higher in Japan and Australia compared to Hong Kong and Singapore. Japan has 34 branches per 100,000 adults and Australia has 30 branches per 100,000 adults. On the other hand, Hong Kong has 23 branches per 100,000 adults and Singapore has 9.5 branches per 100,000 adults. The bank assets to GDP ratio is highest (700\%) in Hong Kong and lowest in Japan (163\%).

Table 3. Regulatory and institutional characteristics of banking systems in developed economies.

\begin{tabular}{ccccc}
\hline Country Name & Australia & Hong Kong & Japan & Singapore \\
\hline Size (USD) & 2.8 trillion & 2.1 trillion & 8 trillion & 779 billion \\
Number of banks & 70 & 56 & 198 & 124 \\
Minimum capital adequacy ratio requirement & $8 \%$ & $8 \%$ & $8 \%$ & $10 \%$ \\
Cash reserve requirement & $0 \%$ & $0 \%$ & $0.1-1.3 \% *$ & $3 \%$ \\
Non-performing loan (NPL) criteria & +90 days & +90 days & +90 days & +90 days \\
Financial inclusion (branches/100,000 adults) & 30 & 23 & 34 & 9.5 \\
Bank assets to GDP ratio & $179 \%$ & $700 \%$ & $163 \%$ & $261 \%$ \\
\hline
\end{tabular}

* Reserve requirements vary by type of financial institution and by size of deposits. Sources: Data related to total assets and number of banks, capital adequacy ratio requirement, cash reserve requirement, and non-performing loan criteria were collected from the websites of central banks. Data related to financial inclusion and bank assets to GDP ratio were collected from the World Bank database.

\section{Literature Review}

There is extensive empirical literature on the relationship between financial sector development and economic growth. Different researchers have used different proxies to measure financial sector development. Bank credit to the private sector, loans, total assets, money supply, deposits, and bank claims are some of the most common proxies used in the literature. A large number of studies have suggested that financial sector development promotes economic growth (Levine 1997) while some studies have also found a negative impact of financial sector development on economic growth (Buffie 1984; Van Wijnbergen 1983). The study by Goldsmith (1969) is one of the earliest studies that investigated the relationship between financial sector development and economic growth. The study used financial institution assets to GDP ratio to measure financial sector development and found that financial sector development promotes economic growth. After Goldsmith, extensive work in this area occurred in the 1990s. Studies by King and Levine (1993a, 1993b) are considered to be benchmark studies. They used various proxies to measure financial inclusion, including current liabilities of the financial sector to GDP ratio, and non-financial private sector liabilities to GDP ratio and non-financial 
private sector liabilities to total credit ratio. They reported that the financial sector promotes economic growth largely as a result of the role played by financial institutions in evaluating promising projects and financing those that are productive and innovative. Levine and Zervos (1998) used the ratio of credit to private sector to GDP as a measure of bank development and found a positive relationship between bank development and long-term economic growth. Levine et al. (2000) used liquid liabilities to GDP ratio, central bank ratio, credit to private sector to GDP ratio, and bank assets to total assets of banking industry ratio to measure financial sector development. They also found a positive relationship between financial sector development on economic growth. Using credit to GDP ratio, Botev et al. (2019) also found a positive relationship between financial sector development and economic growth in developing, emerging, and advanced economies.

Studies that suggest a negative impact of financial sector development on economic growth include those by De Gregorio and Guidotti (1995), La Porta et al. (2002), and Prochniak and Wasiak (2017). Using the ratio of domestic credit to the private sector to GDP as a proxy for financial sector development, De Gregorio and Guidotti (1995) found a negative relationship between financial sector development and economic growth. Similarly, La Porta et al. (2002) also used the ratio of private credit to GDP to measure financial development, and found a negative relationship between financial sector development and economic growth. A study by Prochniak and Wasiak (2017) also found a negative impact of financial sector development (domestic credit as a percentage of GDP) on economic growth.

A number of studies investigated a causal relationship between financial sector development and economic growth. A large number of studies have confirmed that the causal relationship exits but there is still ambiguity on the direction of the causality. Four hypotheses related to the causal relationship between financial sector development and economic growth are supply-leading causality, demand-following causality, bidirectional causality, and no causality. Supply-leading hypothesis indicates that the increase in financial sector development leads to an increase in economic growth (Ahmed and Ansari 1998). According to the demand-following hypothesis, increase in economic growth leads to an increase in financial sector development (Robinson 1952). Bi-directional causality hypothesis suggests that financial sector development promotes economic growth and economic growth promotes financial sector development (Harrison et al. 1999; Patrick 1966). According to the no causality hypothesis, as the name suggests, no relationship exists between financial sector development and economic growth (Lucas 1988).

Pradhan et al. (2014) concluded that causality ran from banking sector development to economic growth in most of the countries in the ASEAN region. Jun (2012) investigated a causal relationship between financial sector development and economic growth in 27 Asian countries using different measures of financial sector development such as liquid liabilities to GDP ratio and domestic credit to GDP ratio. They reported that there is a two-way causal relationship between financial sector development and economic growth. Using different measures of financial sector development, Kar et al. (2011) explored the causality between financial sector development and economic growth. They found evidence for both supply-leading and demand-following hypotheses in Middle East and North African (MENA) countries.

The literature provides evidence of the impact of financial sector development and economic growth and casual relationship between financial sector development and economic growth. Most of these studies have used bank size to measure financial sector development. Therefore, it is unclear whether or not bank profitability promotes economic growth. This study fills the gap by investigating both the impact of bank profitability on economic growth and the direction of the relationship and adds a new strand to the literature on the relationship between financial sector development and economic growth. This study identifies how the impact of bank profitability varies across economies in our sample: Small emerging, large emerging, and developed economies. 


\section{Dependent and Independent Variables}

\subsection{Dependent Variables}

In order to determine the relationship between profitable banks and economic growth, we used yearly GDP growth (\%) as a measure of economic growth. GDP is one of the most widely used indicators of economic growth in previous studies. King and Levine (1993a), Demetriades and Hussein (1996) and Levine et al. (2000) have used GDP growth to establish a link between financial sector development and economic growth.

\subsection{Independent Variables}

We classified explanatory variables into two categories: Key independent variables and control variables. Key independent variables include the lagged value of GDP growth, profitability, and size of the banking sector while control variables include macroeconomic variables and one variable related to the stock market. The variables were selected from a wider number of variables available in the literature. The following section provides the reasons for using these variables and the rationale behind their expected effect.

\subsubsection{Key Independent Variables}

Lagged Gross Domestic Product Growth (Lag GDP) (+): We used lagged GDP growth as a potential determinant of economic growth. Lagged GDP growth has been used in several research studies. Lucas (1988) suggested that GDP growth in period ( $t-1)$ had a positive and significant effect on GDP growth in period $(t)$ in developed and emerging markets. On the other hand, Van Wijnbergen (1983) showed that GDP growth in period ( $t-1)$ had a negative and significant effect on GDP growth in period ( $t$ ) in Turkey. Given that our study focuses on developed and developing countries, in line with the findings of Cole et al. (2008), we hypothesized that lagged GDP growth will have a positive impact on economic growth.

Return on Assets (ROA) (+): We used Return on Assets (ROA) in period ( $t$ ) and ROA in period $(\mathrm{t}-1)$ as measures of profitability. Lagged ROA was used because the profitability of banks may not immediately translate into better economic growth. For standardization purposes, we transformed ROA and lagged ROA into $(1+\mathrm{ROA})$ and lagged $(1+\mathrm{ROA})$. Supporting the view of Athanasoglou et al. (2008) that a profitable banking sector is necessary to drive economic growth, we hypothesized that profitability indicators will have a positive impact on economic growth.

Banking Sector size (SIZE) (+): The most common measure of banking sector size used in previous studies is credit to the private sector; however, some researchers have also used bank loans and deposits as a measure of size. Önder and Özyıldırım (2013) used bank credit as a measure of bank size and found a positive effect of bank credit on economic growth. Shaw (1973) used bank loans and bank deposits as measures of size to investigate their impact on economic growth in China. In both cases, there was a positive impact of size on economic growth in high-income provinces and a negative impact on economic growth in low-income provinces. Taking a more novel approach, Stern (1989) used an interaction variable (R\&D intensity and bank assets) as a proxy for size and concluded that higher growth in the financial sector had a negative impact on productivity growth. We investigated different measures of size but found that the impact of bank assets on economic growth was more significant than the other measures of size. By weight of numbers, previous research has found that bank size has a positive effect on economic growth; therefore, we also hypothesized a positive relationship between bank size and economic growth.

\subsubsection{Control Variables}

Inflation (INF) (-): We measured inflation as the yearly percentage increase in the consumer price index. Most previous studies have found that inflation has a negative impact on economic growth. For example, studies by Koivu (2002), Ndlovu (2013), and Buffie (1984) showed a negative 
and significant impact of inflation on economic growth. Based on these findings, we also hypothesized that inflation will have a negative effect on economic growth.

Government Expenditure (EXP) (+/-): Government expenditure is also referred to as public expenditure. We used annual percentage change in government expenditure as a potential determinant of economic growth. Van Wijnbergen (1983) found that an increase in public expenditure led to an increase in economic growth in Turkey. However, Buffie (1984) suggested that government expenditure had a negative impact on economic growth in 87 developed and developing countries. Taking account of the existing literature, we were unable to predict the sign of the relationship between EXP and economic growth.

Openness of Economy (TRADE) (+): This is measured as the sum of exports and imports of goods and services (Andersen and Babula 2009). A high degree of regulation imposed by a country restricts the degree of openness (Rodriguez and Rodrik 2001). We used annual percentage change in the sum of exports and imports as a potential determinant of economic growth. Based on the study by Buffie (1984), which suggests a positive relationship between trade and economic growth, we also hypothesized that TRADE will have a positive impact on bank profitability.

Stock Market Capitalization (MKTCAP) (+): We used annual percentage change in market capitalization as a potential determinant of economic growth. MKTCAP has been used in a number of studies as a control variable. For example, Ndlovu (2013) used stock market capitalization to determine the causal relationship between the financial sector and economic growth and concluded that MKTCAP does not drive economic growth. In contrast, Goldsmith (1969) suggested that stock market capitalization had a positive and significant impact on economic growth in Taiwan and Korea. Asteriou and Spanos (2019) also found a positive relationship between stock market capitalization and economic growth in EU. Based on the findings of Goldsmith (1969) and Asteriou and Spanos (2019), we hypothesized that MKTCAP will have a positive effect on economic growth.

\section{Data and Methods}

\subsection{Description and Sources of Data}

This study used annual data from ten countries in the Asia-Pacific region, covering the period 2004-2014. The countries were divided into three groups. The first group consisted of small emerging economies: Bangladesh, Indonesia, Malaysia, and Pakistan. The second group comprised large emerging economies: China and India. The third group consisted of developed economies: Australia, Hong Kong, Japan, and Singapore.

In this study, we used the lagged value of GDP growth, profitability, and bank size as key independent variables. We also used three macroeconomic variables: Inflation, government consumption and openness to the economy (trade), and one variable related to the stock market. Data were collected from two sources: The Bureau van Dijk's Bankscope ${ }^{5}$ database and the World Bank database. We collected data for return on assets and bank size from the Bankscope database while World Bank database was used to gather data for other variables such as GDP growth, inflation, government consumption, trade, and market capitalization.

Our dataset consisted of all active commercial banks in the ten previously described countries in the Asia-Pacific region. In some cases, there was duplicate information on a bank where both consolidated and unconsolidated statements were maintained in the database. In these cases, we included only the consolidated statements to avoid duplication. There were some instances where we found statements covering only part of a year (three months or six months), all those observations were excluded.

5 It is a comprehensive database with over 12,000 banks around the world and covers around $90 \%$ of the banks in every country. 


\subsection{Methods}

In most of the existing literature, Ordinary Least Squares (OLS) regression was applied to fixed-effects or random-effects models to deal with simultaneous causality and unobserved heterogeneity. The fixed-effects model estimates parameters for each unit, which not only reduces the power of the model but also results in an increase in the standard errors of the coefficient estimates. It creates more problems when the sample size is small because variation in the dependent variable may be caused by these unit effects (Patrick 1966). On the other hand, a random-effects model lowers the variability within the sample by partially pooling the data. However, fixed-effects and random-effects models do not resolve issues related to endogeneity; therefore, we used the System Generalized Method of Moments (GMM) estimator suggested by Arellano and Bond (1991) to address the endogeneity concerns, including dynamic endogeneity, simultaneity, and time-invariant unobserved heterogeneity across banks. For robustness purposes, we also ran regressions using a pooled OLS estimator. The results were largely consistent with the GMM estimator. ${ }^{6}$

The regression equation that we used is:

$$
\begin{aligned}
G D P_{i t}=\alpha+\beta_{1} G D & P_{i(t-1)}+\beta_{2}(1+R O A)_{i t}+\beta_{3}(1+R O A)_{i(t-1)}+\beta_{4} S I Z E_{i t} \\
& +\beta_{5}(1+R O A)_{i(t-1)} * S I Z E_{i t}+\beta_{6} I N F_{i t}+\beta_{7} M K T C A P_{i t}+\beta_{8} E X P_{i t} \\
& +\beta_{9} T R A D E_{i t}+\text { GFCDummy }+E_{\text {conomyDummies }}
\end{aligned}
$$

where subscript $i$ refers to the country and $t$ refers to the time period. GDP is the GDP growth for a country $i,(1+\mathrm{ROA})$ is the measure of profitability of the banks in country $i$, SIZE refers to the percentage change in the size of the banking sector in country $i$, INF refers to inflation in country $i$, MKTCAP refers to the percentage change in stock market capitalization of country $i$, EXP refers to the percentage change in government expenditure of country $i$, TRADE refers to the percentage change in the sum of exports and imports of country $i$, and GFCdummy is a dummy variable for Global Financial Crisis (GFC).

We ran the regression on the combined countries using a dummy variable for GFC. The dummy variable took a value of 1 for the years 2008 and 2009 and 0 otherwise. We selected years 2008 and 2009 as the GFC period because these were the years when the GFC had a negative impact on the economic growth of the ten countries.

In order to investigate whether the impact of profitability of banks is conditional on the size of the banking sector, we divided banking sectors into large and small, based on the 11-year median result (2004-2014) of the total assets to population ratio for every country. Based on the median results, the large banking sectors were Australia, Japan, Hong Kong, and Singapore and the small banking sectors were Bangladesh, China, India, Indonesia, Malaysia, and Pakistan. The relationship was investigated using the following equation:

$$
G D P_{i t}=\alpha+\beta_{1} G D P_{i(t-1)}+\sum_{j}^{J} \beta_{1} X_{i t}^{j}+\sum_{j=1}^{J} \beta_{2} \mathrm{D}_{1} X_{i t}^{J}+\sum_{l=1}^{L} \beta_{l} X_{i t}^{l}+\epsilon_{i t}
$$

where $X_{i t}^{j}$ refers to bank key independent variables, and $X_{i t}^{l}$ refers to variables related to macroeconomic and stock market capitalization. $D_{1} . X_{i t}$ is the difference between the coefficient values for small banking sectors and large banking sectors. $D_{1}$ takes a value of 1 when the banking sector is large and 0 when the banking sector is small. The sum of $X_{i t}$ and $\mathrm{D}_{1} \cdot X_{i t}$ is the coefficient of the explanatory variables for large banking sectors. In order to find the joint significance of the variables, Wald tests were performed.

6 The results of pooled OLS are not reported but are available on request from the corresponding author. 
In order to investigate the way key explanatory variables impacted on economic growth across the three regions, we used the following equation:

$$
G D P_{i t}=\alpha+\beta_{1} G D P_{i(t-1)}+\sum_{j}^{J} \beta_{1} X_{i t}^{j}+\sum_{j=1}^{J} \beta_{2} \mathrm{D}_{1} X_{i t}^{J}+\sum_{j=1}^{J} \beta_{3} \mathrm{D}_{2} X_{i t}^{J}+\sum_{l=1}^{L} \beta_{l} X_{i t}^{l}+\epsilon_{i t}
$$

where $X_{i t}^{j}$ refers to bank key independent variables, and $X_{i t}^{l}$ refers to variables related to macroeconomic and stock market capitalization. $\mathrm{D}_{1} \cdot X_{i t}$ is the difference between the coefficient values for developed and small emerging economies and $\mathrm{D}_{2} \cdot X_{i t}$ is the difference between the coefficient values for developed and large emerging economies. $\mathrm{D}_{1}$ takes a value of 1 if economies are small emerging and 0 otherwise. $D_{2}$ takes a value of 1 if economies are large emerging and 0 otherwise. The sum of $X_{i t}$ and $D_{1} \cdot X_{i t}$ is the coefficient of the explanatory variables for small emerging economies and the sum of $X_{i t}$ and $\mathrm{D}_{2} \cdot X_{i t}$ is the coefficient of the explanatory variables for large emerging economies. Wald tests were performed to check the joint significance of the variables.

In order to determine a causal relationship between bank profitability and economic growth, we used the Granger causality test. The following equations were used to determine the causal relationship:

$$
\begin{gathered}
G D P_{i t}=\alpha+\beta_{1}(1+R O A)_{i(t-K)}+\beta_{2} G D P_{i(t-K)}+\epsilon_{i t} \\
(1+R O A)_{i t}=\alpha+\beta_{2}(1+R O A)_{i(t-K)}+\beta_{4} G D P_{i(t-K)}+\epsilon_{i t}
\end{gathered}
$$

where subscript $i$ refers to the country and $t$ refers to the time period. GDP is the GDP growth for a country $i,(1+\mathrm{ROA})$ is the measure of profitability of the banks in country $i$. In Equation (4), GDP growth is the dependent variable while in Equation (5), bank profitability (1+ROA) is the dependent variable.

The null hypothesis is that there is no causal relationship between bank profitability and economic growth. Equations (4) and (5) suggest the following relationships:

(a) There will be a unidirectional causality from bank profitability to economic growth if the coefficient of the lagged value of bank profitability is statistically significantly different from zero and the coefficient of the lagged value of GDP is not statistically significant $\left(\beta_{1} \neq 0\right.$ and $\left.\beta_{4}=0\right)$;

(b) There will be a unidirectional causality from economic growth to bank profitability if the coefficient of the lagged value of GDP is statistically significantly different from zero and the coefficient of the lagged value of bank profitability is not statistically significant $\left(\beta_{4} \neq 0\right.$ and $\left.\beta_{1}=0\right)$;

(c) There will be a bi-directional causality between bank profitability and economic growth if the coefficient of the lagged value of GDP and the coefficient of the lagged value of bank profitability are statistically significantly different from zero $\left(\beta_{1} \neq 0\right.$ and $\left.\beta_{4} \neq 0\right)$; and

(d) There will be no causal relationship between bank profitability and economic growth if the coefficient of the lagged value of GDP and the coefficient of the lagged value of bank profitability are not statistically significantly different from zero $\left(\beta_{1}=0\right.$ and $\left.\beta_{4}=0\right)$.

Table 4 provides a summary of the dependent and independent variables, including notation, measurement, and expected effect. We also measured the correlation between explanatory variables and conducted VIF tests. The results, provided in Appendix B, indicate that multicollinearity was not a problem.

Table 5 reports the summary statistics of the variables that were used in the regressions. The results show that over the period 2004-2014, the average GDP growth of the countries in our study was 5.25\%, which was higher than in many other regions/countries such as the European Union (1.12\%), OECD members $(1.55 \%)$, and the United States $(1.72 \%)$ over the same period. The actual growth rates ranged from $-5.53 \%$ to $12.69 \%$. Negative growth was associated with Japan in 2009, while the highest GDP growth was associated with Singapore in 2010. Given the drastic changes in GDP growth, the standard deviation is high at $3.14 \%$. The mean values of profitability measured with $(1+\mathrm{ROA})$ and lagged 
$(1+\mathrm{ROA})$ were 1.11 and 1.12 , respectively. We used the percentage change in banking sector size as a potential determinant of economic growth. The mean value shows that on average the banking sector grew by $5.3 \%$ during the sample period; however, the values range from negative $15.82 \%$ to positive $22.16 \%$, with a standard deviation of $10.1 \%$.

Table 4. Definition, notation, and expected effect of the variables.

\begin{tabular}{|c|c|c|c|}
\hline Variables & Notation & Measure & Expected Sign \\
\hline $\begin{array}{l}\text { Dependent Variable } \\
\text { Gross Domestic Product } \\
\text { Independent Variables } \\
\text { Key Independent Variables }\end{array}$ & GDP & Annual GDP growth rate (\%) & \\
\hline Lagged Gross Domestic Product & Lag GDP & $\begin{array}{l}\text { Lagged value of annual GDP growth rate } \\
\qquad(\%)\end{array}$ & + \\
\hline Return on Assets & $\mathrm{ROA}$ & $(1+$ Profit before tax/Total assets $)$ & + \\
\hline Lagged (1 + Return on Assets) & Lag ROA & $\begin{array}{c}\text { Lagged value of }(1+\text { Profit before tax/Total } \\
\text { assets })\end{array}$ & + \\
\hline Banking Sector Size & SIZE & $\begin{array}{c}\text { Annual percentage change in total bank } \\
\text { assets (\%) }\end{array}$ & + \\
\hline $\begin{array}{l}\text { Control Variables } \\
\text { Inflation }\end{array}$ & INF & Annual percentage change in CPI (\%) & - \\
\hline Government Consumption & EXP & $\begin{array}{c}\text { Annual percentage change in government } \\
\text { consumption }(\%)\end{array}$ & $+/-$ \\
\hline Openness to Economy & TRADE & $\begin{array}{c}\text { Annual percentage change in sum of } \\
\text { exports and imports }(\%)\end{array}$ & + \\
\hline Stock Market Capitalization & MKTCAP & $\begin{array}{c}\text { Annual percentage change in market } \\
\text { capitalization }(\%)\end{array}$ & + \\
\hline
\end{tabular}

A "+" sign shows that we expect a positive relationship between the dependent variable and the independent variable. A "-" sign shows that we expect a negative relationship between the dependent variable and the independent variable. A "+/" sign shows that there is a reason to believe the relationship could go in either direction. Source: Data for bank-related variables such as return on assets and bank size were collected from the Bankscope database. The data for other variables, including GDP growth, inflation, government consumption, trade, and market capitalization were gathered from the World Bank database.

Table 5. Descriptive statistics (number of observations $=110$ ).

\begin{tabular}{ccclc}
\hline Variable & Mean & Std. Dev. & Min & Max \\
\hline GDP & 5.25 & 3.141 & -1.51 & 12.69 \\
Lag GDP & 5.2 & 3.20 & -1.51 & 12.69 \\
(1 + ROA) & 1.10 & 0.37 & 0.31 & 1.83 \\
Lag (1 + ROA) & 1.12 & 0.38 & 0.31 & 1.83 \\
SIZE (Change in total assets) & 5.30 & 10.99 & -15.82 & 22.16 \\
INF & 4.72 & 3.68 & -0.7 & 13.65 \\
EXP & 10.51 & 9.18 & -7.77 & 31.43 \\
TRADE & -1.97 & 11.31 & -37.48 & 16.47 \\
MKTCAP & 8.93 & 40.47 & -64 & 110.01 \\
\hline
\end{tabular}

These variables were selected from a number of available variables. We measured the correlation between explanatory variables and conducted VIF tests for individual countries and for aggregate data; explanatory variables with correlations of more than 0.8 or VIF values greater than 10 were omitted from the regressions. Source: Authors' calculations.

Turning to macroeconomic variables, the mean value of INF was $4.72 \%$, which was higher than many other regions/countries such as the European Union (2.22\%), OECD members (2.19\%), and the United States $(2.33 \%)$. It indicates that inflation rose significantly in some of the countries in the sample during the period of study. The values ranged from $-0.7 \%$ to $13.65 \%$. Japan witnessed a negative inflation rate $(0.7 \%)$ in 2010 while Pakistan had the highest inflation rate in 2008. The percentage change in government expenditure (EXP) shows that the average growth in government expenditure was $10.51 \%$ in the sampled countries. It was higher than the European Union (3.6\%), OECD members $(3.7 \%)$, and the United States (3.2\%). The mean value of the percentage change in TRADE was $-1.98 \%$, which indicates that the value of trade declined over the duration of the study. However, trade also 
declined in the European Union $(-4.48 \%)$, OECD members $(-4.8 \%)$, and the United States $(-4.6 \%)$ during the same period. We also used the percentage change in stock market capitalization as an explanatory variable. The results show that the average growth in market capitalization was $8.93 \%$ over the period 2004-2014. The growth in stock market capitalization was more than in the European Union $(6.6 \%)$, OECD members $(-0.3 \%)$, and the United States $(-2 \%)$ during the same period.

\section{Empirical Results}

\subsection{Regression Results}

Table 6 reports the regression results for the combination of all countries. For Columns 1 to 4 , the results were obtained using a regression equation as provided in Equation (1). For Column 5, results were obtained using a regression as set out in Equation (2). In Columns 1 and 2, we show results for regressions that included all of the key independent variables and dummy variables for GFC. In Column 3, we introduce the macroeconomic and stock market variables, while in Columns 4 and 5 we introduce cross-product terms for bank profitability and size.

Table 6. Regression results using the system generalized method of moments (GMM) estimator.

\begin{tabular}{|c|c|c|c|c|c|}
\hline Dependent Variable: GDP Growth (\%) & (1) & (2) & (3) & (4) & (5) \\
\hline \multicolumn{6}{|l|}{ Explanatory Variables } \\
\hline \multicolumn{6}{|l|}{ Key independent variables } \\
\hline Lag GDP & $\begin{array}{l}0.106 \\
(1.09)\end{array}$ & $\begin{array}{l}0.108 \\
(1.11)\end{array}$ & $\begin{array}{l}0.121 \\
(1.28)\end{array}$ & $\begin{array}{l}0.0378 \\
(0.39)\end{array}$ & $\begin{array}{c}0.00240 \\
(0.02)\end{array}$ \\
\hline $\operatorname{Lag}(1+\mathrm{ROA})$ & $\begin{array}{c}4.581^{* * *} \\
(3.24)\end{array}$ & $\begin{array}{l}4.293^{* * *} \\
(2.96)\end{array}$ & $\begin{array}{l}4.282^{* * *} \\
(3.07)\end{array}$ & $\begin{array}{l}7.26^{* * *} \\
(3.19)\end{array}$ & \\
\hline$(1+\mathrm{ROA})$ & & $\begin{array}{l}0.848 \\
(0.61)\end{array}$ & & & \\
\hline Lag $(1+\mathrm{ROA})$ - Small banking sectors & & & & & $\begin{array}{l}8.74 * \\
(1.85)\end{array}$ \\
\hline Lag $(1+\mathrm{ROA})$-Large banking sectors & & & & & $\begin{array}{c}5.483^{* * *} \\
(3.78)\end{array}$ \\
\hline SIZE (Change in total assets) & $\begin{array}{c}-0.0459 * * \\
(-2.37)\end{array}$ & $\begin{array}{c}-0.0461 * * \\
(-2.34)\end{array}$ & $\begin{array}{c}-0.0121 * \\
(-1.89)\end{array}$ & $\begin{array}{c}-0.0321 \\
(-1.62)\end{array}$ & $\begin{array}{c}-0.0376 \\
(-1.49)\end{array}$ \\
\hline $\operatorname{Lag}(1+\mathrm{ROA})^{*} \mathrm{SIZE}$ & & & & $\begin{array}{c}-0.891 \text { ** } \\
(-2.44)\end{array}$ & \\
\hline Lag $(1+\mathrm{ROA}) *$ SIZE—Small banking sectors & & & & & $\begin{array}{c}-1.118^{* *} \\
(-2.11)\end{array}$ \\
\hline Lag $(1+\mathrm{ROA}) *$ SIZE—Large banking sectors & & & & & $\begin{array}{c}-0.0330 * \\
(-1.67)\end{array}$ \\
\hline \multicolumn{6}{|l|}{ Control variables } \\
\hline INF & & & $\begin{array}{l}-0.134 \\
(-1.08)\end{array}$ & $\begin{array}{l}-0.200 * \\
(-1.66)\end{array}$ & $\begin{array}{l}-0.198 \\
(-1.63)\end{array}$ \\
\hline EXP & & & $\begin{array}{c}0.101 * * * \\
(3.97)\end{array}$ & $\begin{array}{l}0.0697^{* * *} \\
(2.63)\end{array}$ & $\begin{array}{l}0.0637^{* *} \\
(2.39)\end{array}$ \\
\hline TRADE & & & $\begin{array}{l}0.0180 \\
(0.84)\end{array}$ & $\begin{array}{r}0.0107 \\
(0.51)\end{array}$ & $\begin{array}{c}0.00839 \\
(0.40)\end{array}$ \\
\hline MKTCAP & & & $\begin{array}{c}0.00908 \text { * } \\
(1.78)\end{array}$ & $\begin{array}{c}0.00515 \\
(0.95)\end{array}$ & $\begin{array}{c}0.00440 \\
(0.82)\end{array}$ \\
\hline During GFC & $\begin{array}{c}-2.309 * * * \\
(-4.87)\end{array}$ & $\begin{array}{c}-2.265 * * * \\
(-4.65)\end{array}$ & $\begin{array}{c}-2.111 * * * \\
(-4.36)\end{array}$ & $\begin{array}{c}-2.442 * * * \\
(-5.00)\end{array}$ & $\begin{array}{c}-2.411^{* * *} \\
(-4.77)\end{array}$ \\
\hline Constant & $\begin{array}{l}0.230 \\
(0.14) \\
\end{array}$ & $\begin{array}{l}-0.406 \\
(-0.21) \\
\end{array}$ & $\begin{array}{l}-0.199 \\
(-0.12) \\
\end{array}$ & $\begin{array}{c}0.0314 \\
(0.02) \\
\end{array}$ & $\begin{array}{l}0.921 \\
(0.35) \\
\end{array}$ \\
\hline Number of countries & 10 & 10 & 10 & 10 & 10 \\
\hline Number of banks & 654 & 654 & 654 & 654 & 654 \\
\hline $\operatorname{AR}(1)$ ( $p$-value) & 0.0233 & 0.0289 & 0.0289 & 0.0461 & 0.0265 \\
\hline $\operatorname{AR}(2)(p$-value $)$ & 0.3128 & 0.3111 & 0.3111 & 0.3044 & 0.2357 \\
\hline Sargan test ( $p$-value) & 0.962 & 0.894 & 0.605 & 0.729 & 0.978 \\
\hline
\end{tabular}

The results are obtained using Equations (1) and (2). Standard errors in parentheses. ${ }^{* * *} p<0.01, * * p<0.05$, and ${ }^{*} p<0.1$. The results of Sargan tests confirm that all the instruments employed in the GMM model are appropriate. Source: Authors' calculations. 
The $p$-values of Sargan tests were greater than 0.1 ; therefore, we could not reject the null hypothesis, suggesting that there is no evidence of over-identifying restrictions. The absence of second-order autocorrelation showed that the estimates were consistent (see Table 6).

In Model 1, the coefficient of lagged profitability was positive and statistically significant, suggesting a positive relationship between bank profitability and GDP growth. In Model 2, we included a contemporaneous measure of profitability along with a lagged value of profitability. However, when both contemporaneous and lagged profitability measures were used simultaneously in the regression in Model 2, only the lagged value of profitability remained significant. Hence, when we introduced the macroeconomic and market variables in Model 3, we only included the lagged profitability variable, whose sign remained positive and highly significant. Our results confirmed that the positive impact that bank profitability has on economic growth is slow in its transition. If banks are profitable, they will be able to transfer an increasing volume of funds from savers to users, which will generate economic activity and promote economic growth. In contrast, it is a risk to the economy if banks are not financially sound as they will not be able to efficiently perform their intermediary functions. Our findings associated with a positive impact of bank profitability on economic growth provide support for the proposition made by Athanasoglou et al. (2008) that a well-functioning and profitable banking sector is necessary to drive economic growth.

Somewhat unexpectedly, the coefficient for our size variable was negative and weakly significant in our first three models. This finding is in contrast with the literature and our expectations; however, some other studies have also found that bank size is negatively correlated to economic growth. For example, La Porta et al. (2002) and Prochniak and Wasiak (2017) found a negative impact of financial sector size on economic growth in OECD and European Union countries. Bank size is measured against the total assets of the banking sector and the assets include bank loans extended to public and private sectors. Businesses need to pay interest on these loans. Businesses devote significant resources to repaying interest and loan. In such cases, businesses have limited resources to stimulate economic growth (Prochniak and Wasiak 2017).

We next decided to introduce a cross-product term $(\operatorname{Lag}(1+\mathrm{ROA}) \times$ SIZE) involving profitability and size in order to examine the joint impact that these variables have on economic growth (Model 4). We found that this cross-product term had a negative sign and was significant, indicating the positive impact that lagged profitability had on economic growth was weaker for the faster-growing banks, as shown below:

$$
\frac{\Delta G D P}{\text { Lagged }(1+R O A)}=7.26-0.891(5.3)=2.54
$$

The coefficient for lagged $(1+\mathrm{ROA})$ was 7.26 while the coefficient for the cross-product term was -0.891 . The average growth in bank size was $5.3 \%$. The result shows that increased bank profitability increases GDP growth.

$$
\frac{\Delta G D P}{S I Z E}=-0.0321-0.891(1.122)=-1.03
$$

The coefficient for bank size was -0.0321 while the coefficient for the cross-product term was -0.891 . The average profitability was 1.122 . The results indicate that increased bank size reduces bank profitability.

In Model 5, we divided the ten banking sectors into large and small banking sectors based on their bank assets to population ratios. In both the large and small banking sectors, we found a positive relationship between the lagged value of profitability and GDP growth. However, the coefficients for small banking sectors (8.74) and for large banking sectors (5.48) showed that the impact bank profitability has on economic growth is larger in those countries with smaller banking sectors. We also introduced a cross-product term $(\operatorname{Lag}(1+\mathrm{ROA}) \times$ SIZE) for both small and large banking sectors to examine the joint impact that these variables have on economic growth. The coefficient of the cross-product term for both large and small banking sectors was negative and significant: -0.033 for large banking sectors and -1.118 for small banking sectors. This shows that in both cases the 
cross-product term had a negative impact on economic growth, with this negative impact being larger for the smaller banking sectors, as shown below.

Small banking sectors:

$$
\frac{\Delta G D P}{\text { Lagged }(1+R O A)}=8.74-1.118(3.8)=4.50
$$

The coefficient for lagged $(1+\mathrm{ROA})$ is 8.74 while the coefficient for the cross-product term was -1.118 . The average growth in bank size of small banking sectors was $3.8 \%$. The result (4.50) shows that increased bank profitability increases GDP growth.

$$
\frac{\Delta G D P}{S I Z E}=-0.0376-1.118(1.2)=-1.38
$$

The coefficient for bank size was -0.0376 while the coefficient for the cross-product term was -1.118 . The average profitability of small banking sectors was 1.2. The result shows that increased bank size reduces bank profitability.

Large banking sectors:

$$
\frac{\Delta G D P}{\text { Lagged }(1+R O A)}=5.483-0.033(7.56)=5.23
$$

The coefficient for lagged $(1+\mathrm{ROA})$ was 5.489 while the coefficient for the cross-product term was -0.033 . The average growth in bank size of large banking sectors was $7.56 \%$. The result (5.23) shows that increased bank profitability increases GDP growth.

$$
\frac{\Delta G D P}{S I Z E}=-0.0376-0.0330(0.95)=-0.07
$$

The coefficient for bank size was -0.0376 while the coefficient for the cross-product term was -0.0330 . The average profitability of large banking sectors was 0.95 . The result shows that increased bank size reduces bank profitability.

The overall results for small banking sectors and large banking sectors clearly show that the positive impact of banking profitability on GDP growth and the negative impact of bank size are much larger in the case of small banking sectors. We used a dummy variable for GFC, which was designated as applying in 2008 and 2009. The coefficient was negative and statistically significant, which is consistent with economic growth decreasing during the GFC.

In terms of macroeconomic variables, we found weak evidence to suggest a negative relationship between inflation and GDP growth. The finding is consistent with our expectations and the findings in previous studies such as those by Ndlovu (2013) and Asteriou and Spanos (2019). We also found that an increase in government expenditure led to an increase in economic growth. Again, it is not surprising to find that government expenditure that includes education, health, and infrastructure has a positive impact on economic growth. This finding is consistent with Van Wijnbergen (1983), who also found weak evidence to suggest that government expenditure leads to an increase in economic growth. We also found weak evidence to suggest that growth in stock market capitalization led to an increase in the rate of economic growth, which is consistent with the findings of Goldsmith (1969) and Asteriou and Spanos (2019). We found trade to be the only macroeconomic variable we included that did not influence economic growth.

\subsection{Effect of Key Variables across Developed, Small Emerging, and Large Emerging Economies}

Table 7 shows how the impact of the lagged value of the profitability measure $(1+\mathrm{ROA})$ and an interaction variable (lagged value of ROA $\times$ SIZE) differed across developed, small emerging, and large emerging economies. The results were obtained via a regression, as set out in Equation (3). 
Table 7. Effect of lagged profitability and interaction term (lagged profitability*bank size) on economic growth.

\begin{tabular}{ccc}
\hline Subsamples & Lag $(1+$ ROA $)$ & Lag $(1+\text { ROA })^{*}$ SIZE \\
\hline Developed $\left(\mathrm{B}_{0} \cdot X_{i t}\right)$ & $9.626^{* * *}$ & -0.257 \\
$\mathrm{~B}_{1} \cdot \mathrm{D}_{1} \cdot X_{i t}$ & $-3.710^{* * *}$ & $-0.309^{* * *}$ \\
$\mathrm{~B}_{2} \cdot \mathrm{D}_{2} \cdot X_{i t}$ & -4.720 & -0.236 \\
Small Emerging $\left(\mathrm{B}_{0}+\mathrm{B}_{1}\right)$ & $5.916^{* * *}$ & $-0.566^{* * *}$ \\
Large Emerging $\left(\mathrm{B}_{0}+\mathrm{B}_{2}\right)$ & $4.906^{* * *}$ & $-0.493^{* *}$
\end{tabular}

The table reports the results for the regression Equation (3). Our dependent variable is economic growth. ${ }^{* * *} p<0.01$, ** $p<0.05$. $X_{i t}$ is the coefficient for the explanatory variables for developed economies, D1. $X_{i t}$ is the difference between the coefficient values for developed and small emerging economies and $\mathrm{D}_{2} \cdot X_{i t}$ is the difference between the coefficient values for developed and large emerging economies. $D_{1}=1$ if small emerging, 0 otherwise and $D_{2}=1$ if large emerging and 0 otherwise. The sum of $X_{i t}$ and $D_{1} \cdot X_{i t}$ is the coefficient for the explanatory variables for small emerging economies and the sum of $X_{i t}$ and $\mathrm{D}_{2} \cdot X_{i t}$ is the coefficient for the explanatory variables for large emerging economies. Source: Authors' calculations.

Our results highlight that there was some variation between the impact of the lagged value of profitability measure $(1+\mathrm{ROA})$ and the impact of an interaction variable (lagged value of $\mathrm{ROA} \times$ SIZE) on economic growth across the economies at different stages of development.

Lagged profitability had a positive and significant impact on economic growth in all three types of economies. However, the coefficient shows that the impact was larger for developed economies than for small emerging or large emerging economies. These results are consistent with our pooled regression results in Table 6.

The coefficients for the interaction variables (lagged value of ROA $\times$ SIZE) for small emerging economies and large emerging economies were -0.566 and -0.493 , respectively. In both cases the relationship was significant. This indicates that the impact of lagged profitability on economic growth was weaker for faster-growing banks in small emerging and large emerging economies. In the case of the developed economies, the coefficient was also negative but statistically insignificant. Overall, the results suggest that an increase in profitability leads to an increase in economic growth, while an increase in banking sector size leads to a decrease in economic growth in small emerging and large emerging economies.

\subsection{Bank Profitability and Economic Growth-A Causality Analysis}

Table 8 reports the results of Granger causality tests to investigate the causal relationship between bank profitability and economic growth. The results were obtained using a regression, as set out in Equations (4) and (5). The null hypotheses were: (i) Bank profitability (1 + ROA) does not cause GDP growth and (ii) GDP growth does not cause bank profitability $(1+\mathrm{ROA})$. We used a lag order of 1 and a lag order of 2 to determine the causal relationships.

Table 8. Granger causality results.

\begin{tabular}{ccc}
\hline Null Hypothesis & Lag Order: 1 & Lag Order: 2 \\
\hline $\mathrm{H}_{0}$ : Bank profitability does not Granger-cause GDP Growth. & $p$-Value & $p$-Value \\
$\mathrm{H}_{0}$ : GDP Growth does not Granger-cause Bank profitability. & $0.000^{* * *}$ & $0.000^{* * *}$ \\
\hline The table reports the results for Equations (4) and (5). ${ }^{* * *}$ significant at the $1 \%$ level. Source: Authors' calculations.
\end{tabular}

The results suggest that unidirectional causality runs from bank profitability ( $1+$ ROA) to GDP growth at lag order 1 while at lag order 2, our results suggest a bi-directional causal relationship between bank profitability and GDP growth. This indicates that the impact of bank profitability on GDP growth is immediate, while GDP growth has some delayed feedback on bank profitability. Overall, the causality results suggest that it is bank profitability that influences economic growth to 
a large extent in the Asia-Pacific region. This is also consistent with the results of contemporaneous relationships between bank profitability and GDP growth as shown in Table 6.

\section{Conclusions}

This study investigated the relationship between the profitability of banks and economic growth in ten countries across the Asia-Pacific region in the period from 2004 to 2014 . We started with the proposition that a national economy cannot run smoothly without a well-functioning and profitable banking sector. Our results showed that there was a positive and statistically significant relationship between the profitability of banks and economic growth. However, the impact that bank profitability had on economic growth was slow to take effect. In relation to bank size, our findings are interesting. Our results showed that increases in bank size had a negative impact on economic growth, which was not consistent with our expectations. Overall, our results suggest that an increase in the profitability of the banking sector leads to an increase in economic growth, while an increase in the size of the banking sector leads to a decrease in economic growth. The causality results suggest that bank profitability fosters economic growth, and that GDP growth has a delayed feedback effect on bank profitability. Furthermore, our results suggest that the impact of bank profitability on economic growth decreases when the size of the banking sector increases.

In line with our expectations, we found that economic growth was hampered during the Global Financial Crisis. Our results indicate that inflation has a negative effect on economic growth, and that increases in government expenditure on health, education, and infrastructure lead to an increase in economic growth.

One other question of interest is: Do the explanatory variables impact differently on different types of economies? Our results show that the impact of lagged value on profitability was larger for developed economies than for small emerging and large emerging economies. In addition, our results for the interaction term (lagged value of ROA $\times$ SIZE) suggest that an increase in profitability leads to an increase in economic growth, while an increase in banking sector size leads to a decrease in economic growth in small emerging and large emerging economies. In the case of developed economies, the coefficient is also negative but statistically insignificant.

Overall, our results support the view of Athanasoglou et al. (2008) that bank profitability is a prerequisite for economic growth. Policy makers should be aware of the impact that policies and regulations will have on bank profitability because of the possible knock-on impact they may have on the economy.

Author Contributions: Conceptualization, V.K. and R.B.; methodology, V.K.; software, V.K.; validation, V.K. and R.B.; formal analysis, V.K.; investigation, V.K. and R.B.; resources, V.K.; data curation, V.K.; writing-original draft preparation, V.K.; writing-review and editing, R.B.; visualization, V.K.; supervision, R.B.; project administration, V.K. All authors have read and agreed to the published version of the manuscript.

Funding: This research received no external funding.

Conflicts of Interest: The authors declare no conflict of interest. 


\section{Appendix A}

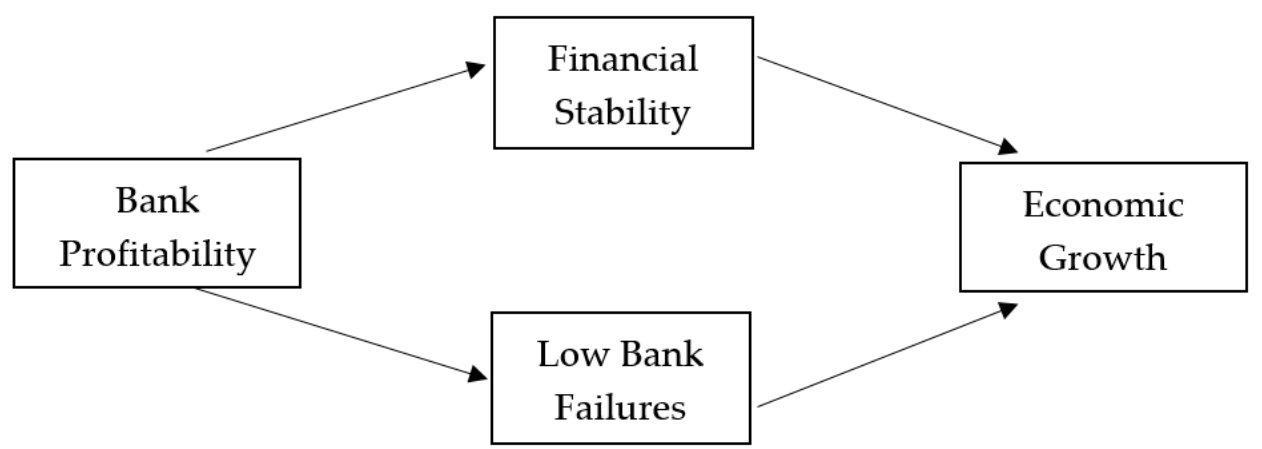

Figure A1. Conceptual nexus between bank profitability and economic growth. Notes: The figure shows that bank profitability leads to financial stability and results in low bank failures. Both financial stability and low bank failures promote economic growth.

\section{Appendix B}

Table A1. Correlation matrix for variables.

\begin{tabular}{cccccccc}
\hline Correlation Matrix & GDP & $\mathbf{( 1 + R O A )}$ & SIZE & INF & EXP & TRADE & MKTCAP \\
\hline GDP & 1 & & & & & & \\
$(1+$ ROA $)$ & 0.49 & 1 & & & & & \\
SIZE & -0.19 & -0.04 & 1 & & & & \\
INF & 0.15 & 0.33 & -0.23 & 1 & & & \\
EXP & 0.48 & 0.35 & -0.33 & 0.21 & 1 & & \\
TRADE & 0.02 & -0.02 & -0.13 & -0.03 & -0.07 & 1 & \\
MKTCAP & 0.18 & 0.03 & 0.17 & -0.09 & -0.08 & -0.09 & \\
\hline
\end{tabular}

Source: Authors' calculations.

Table A2. Vector inflation factor.

\begin{tabular}{clc}
\hline Variable & VIF & 1/VIF \\
\hline$(1+$ ROA $)$ & 4.81 & 0.20 \\
INF & 1.95 & 0.51 \\
SIZE & 1.84 & 0.54 \\
EXP & 1.24 & 0.81 \\
PSC & 1.2 & 0.83 \\
NPLS & 1.14 & 0.88 \\
TRADE & 1.11 & 0.90 \\
MKTCAP & 1.09 & 0.92 \\
\hline Mean VIF & 2.06 \\
\hline \multicolumn{3}{c}{ Source: Authors' calculations. }
\end{tabular}

\section{References}

Ahmed, Syed M., and Mohammed I. Ansari. 1998. Financial sector development and economic growth: The South-Asian experience. Journal of Asian Economics 9: 503-17. [CrossRef]

Anandarajan, Asokan, Iftekhar Hasan, and Cornelia McCarthy. 2007. Use of loan loss provisions for capital, earnings management and signalling by Australian banks. Accounting E Finance 47: 357-79.

Anari, Ali, James Kolari, and Joseph Mason. 2005. Bank asset liquidation and the propagation of the US Great Depression. Journal of Money, Credit and Banking 37: 753-73. [CrossRef] 
Andersen, Lill, and Ronald Babula. 2009. The link between openness and long-run economic growth. Journal of International Commerce Economics 2: 31-50.

Arellano, Manuel, and Stephen Bond. 1991. Some Tests of Specification for Panel Data: Monte Carlo Evidence and an Application to Employment Equations. The Review of Economic Studies 58: 277-97. [CrossRef]

Asteriou, Dimitrios, and Konstantinos Spanos. 2019. The relationship between financial development and economic growth during the recent crisis: Evidence from the EU. Finance Research Letters 28: $238-45$. [CrossRef]

Athanasoglou, Panayiotis P., Sophocles N. Brissimis, and Matthaios D. Delis. 2008. Bank-specific, industry-specific and macroeconomic determinants of bank profitability. Journal of international Financial Markets, Institutions and Money 18: 121-36. [CrossRef]

Bernanke, Ben S. 1983. Nonmonetary Effects of the Financial Crisis in the Propagation of the Great Depression. The American Economic Review 73: 257-76.

Botev, Jaroslava, Balázs Égert, and Fredj Jawadi. 2019. The nonlinear relationship between economic growth and financial development: Evidence from developing, emerging and advanced economies. International Economics 160: 3-13. [CrossRef]

Buffie, Edward F. 1984. Financial repression, the new structuralists, and stabilization policy in semi-industrialized economies. Journal of Development Economics 14: 305-22. [CrossRef]

Calomiris, Charles W., and Joseph R. Mason. 2003. Consequences of bank distress during the Great Depression. American Economic Review 93: 937-47. [CrossRef]

Claeys, Sophie, and Koen Schoors. 2007. Bank supervision Russian style: Evidence of conflicts between micro-and macro-prudential concerns. Journal of Comparative Economics 35: 630-57. [CrossRef]

Cole, Rebel A., Fariborz Moshirian, and Qiongbing Wu. 2008. Bank stock returns and economic growth. Journal of Banking E Finance 32: 995-1007.

Creel, Jérôme, Paul Hubert, and Fabien Labondance. 2015. Financial stability and economic performance. Economic Modelling 48: 25-40. [CrossRef]

De Gregorio, Jose, and Pablo E. Guidotti. 1995. Financial development and economic growth. World Development 23: 433-48. [CrossRef]

Demetriades, Panicos O., and Khaled A. Hussein. 1996. Does financial development cause economic growth? Time-series evidence from 16 countries. Journal of Development Economics 51: 387-411. [CrossRef]

Dia, Mohamed, Amirmohsen Golmohammadi, and Pawoumodom M. Takouda. 2020. Relative Efficiency of Canadian Banks: A Three-Stage Network Bootstrap DEA. Journal of Risk and Financial Management 13: 68. [CrossRef]

Dietrich, Andreas, and Gabrielle Wanzenried. 2011. Determinants of bank profitability before and during the crisis: Evidence from Switzerland. Journal of International Financial Markets, Institutions and Money 21: 307-27. [CrossRef]

European Central Bank. 2016. Financial Stability Review. Available online: https://www.ecb.europa.eu/pub/pdf/ other/financialstabilityreview201611.en.pdf (accessed on 1 March 2020).

Goldsmith, Raymond William. 1969. Financial Structure and Development. No. HG174 G57. New Haven: Yale University Press.

Harrison, Paul, Oren Sussman, and Joseph Zeira. 1999. Finance and Growth: Theory and New Evidence. Available online: https://papers.ssrn.com/sol3/papers.cfm?abstract_id=186142 (accessed on 4 April 2020).

Jun, Sangjoon. 2012. Financial development and output growth: A panel study for Asian countries. Journal of East Asian Economic Integration 16: 97-115. [CrossRef]

Kar, Muhsin, Şaban Nazlığlu, and Hüseyin Ağır. 2011. Financial development and economic growth nexus in the MENA countries: Bootstrap panel granger causality analysis. Economic Modelling 28: 685-93. [CrossRef]

King, Robert G., and Ross Levine. 1993a. Finance and growth: Schumpeter might be right. The Quarterly Journal of Economics 108: 717-37. [CrossRef]

King, Robert G., and Ross Levine. 1993b. Finance, entrepreneurship and growth. Journal of Monetary Economics 32: 513-42. [CrossRef]

Klein, Paul-Olivier, and Laurent Weill. 2017. Bank Profitability: Good for Growth? Working Paper 2017-02. Paris: Institut de France.

Koivu, Tuuli. 2002. Do Efficient Banking Sectors Accelerate Economic Growth in Transition Countries? Available online: https://papers.ssrn.com/sol3/papers.cfm?abstract_id=1015710 (accessed on 12 February 2020). 
Kumar, Vijay, Sanjeev Acharya, and Ly TH Ho. 2020. Does monetary policy influence the profitability of banks in New Zealand? International Journal of Financial Studies 8: 35. [CrossRef]

La Porta, Rafael, Florencio Lopez-de-Silanes, and Andrei Shleifer. 2002. Government ownership of banks. The Journal of Finance 57: 265-301. [CrossRef]

Levine, Ross. 1997. Financial Development and Economic Growth: Views and Agenda. Journal of Economic Literature 35: 688-726.

Levine, Ross, and Sara Zervos. 1998. Stock markets, banks, and economic growth. American Economic Review 88: 537-58.

Levine, Ross, Norman Loayza, and Thorsten Beck. 2000. Financial intermediation and growth: Causality and causes. Journal of Monetary Economics 46: 31-77. [CrossRef]

Lucas, Robert E. 1988. On the mechanics of economic development. Journal of Monetary Economics 22: 3-42. [CrossRef]

Ndlovu, Godfrey. 2013. Financial sector development and economic growth: Evidence from Zimbabwe. International Journal of Economics and Financial Issues 3: 435.

Önder, Zeynep, and Süheyla Özyıldırım. 2013. Role of bank credit on local growth: Do politics and crisis matter? Journal of Financial Stability 9: 13-25. [CrossRef]

Patrick, Hugh T. 1966. Financial development and economic growth in underdeveloped countries. Economic Development and Cultural Change 14: 174-89. [CrossRef]

Pradhan, Rudra P., Mak B. Arvin, John H. Hall, and Sahar Bahmani. 2014. Causal nexus between economic growth, banking sector development, stock market development, and other macroeconomic variables: The case of ASEAN countries. Review of Financial Economics 23: 155-73. [CrossRef]

Prochniak, Mariusz, and Katarzyna Wasiak. 2017. The impact of the financial system on economic growth in the context of the global crisis: empirical evidence for the EU and OECD countries. Empirica 44: 295-337. [CrossRef]

Robinson, Joan. 1952. The Rate of Interest and Other Essays. London: MacMillan.

Rodriguez, Francisco, and Dani Rodrik. 2001. Trade policy and economic growth: a skeptic's guide to the cross-national evidence. Edited by Ben S. Bernanke and Kenneth S. Rogoff. NBER Macroeconomics Annual 200: 261-338.

Shaw, Edward Stone. 1973. Financial Deepening in Economic Development. New York: Oxford University press.

Stern, Nicholas. 1989. The economics of development: a survey. The Economic Journal 99: 597-685. [CrossRef]

Trujillo-Ponce, Antonio. 2013. What determines the profitability of banks? Evidence from Spain. Accounting $\mathcal{E}$ Finance 53: 561-86.

Van Wijnbergen, Sweder. 1983. Interest rate management in LDC's. Journal of Monetary Economics 12: 433-52. [CrossRef]

Wachtel, Paul. 2001. Growth and Finance: What do we know and how do we know it? International Finance 4: 335-62. [CrossRef]

World Bank. 2005. Financial Sector Assessment-A Handbook. Washington, DC: World Bank.

(C) 2020 by the authors. Licensee MDPI, Basel, Switzerland. This article is an open access article distributed under the terms and conditions of the Creative Commons Attribution (CC BY) license (http://creativecommons.org/licenses/by/4.0/). 